\title{
Relations with wildlife of Wichi and Criollo people of the Dry Chaco, a conservation perspective
}

\author{
Micaela Camino ${ }^{1,2,3,4}$; Sara Cortez ${ }^{4}$, Mariana Altrichter ${ }^{5,6}$; Silvia D. Matteucci ${ }^{2,7}$
}

\begin{abstract}
Indigenous Wichís and mestizos Criollos inhabit a rural, biodiversity rich, area of the Argentinean Dry Chaco. Traditionally, Wichís were nomads and their relations with wildlife were shaped by animistic and shamanic beliefs. Today, Wichís live in stable communities and practice subsistence hunting, gathering and in some cases, fishing. Criollos are mestizos, i.e. a mixture of the first Spanish settlers and different indigenous groups. They arrived during the 20th century from neighbouring Provinces. They practice extensive ranching, hunting and gathering. Our aim was to help develop effective and legitimate actions to conserve wildlife species in this region, focused on Wichís' and Criollos' perceptions of and relations with wildlife. We conducted semi-structured interviews $(\mathrm{N}=105)$ in rural settlements. We found differences in both groups' hunting techniques, drivers and perceptions on the importance of wild meat for nutrition. However, both groups have a close relation with wildlife, they use wild animals in a variety of ways, including as food resource, medicine and predictors of future events. Wichís and Criollos also relate with wildlife in a spiritual dimension, have animistic and shamanic beliefs and have unique traditional ecological knowledge. Hunters in both communities are breaking traditional hunting norms but conservation measures grounded on these norms have a higher probability of success. Management recommendations include developing programmes focused on (i) conserving thin armadillos; (ii) conserving pregnant and breeding females of all species; (iii) managing dogs to avoid unnecessary killings and on (iv) improving local livelihoods. We also provide recommendations that are specific for each group.
\end{abstract}

Keywords: Conservation; Local Cultures; Subsistence Hunting; Chaco; Indigenous People; Mestizo People

\footnotetext{
${ }^{1}$ Laboratory of Conservation Biology of the Centre of Applied Ecology of the Litoral Region (CECOAL). National Road 5, km2.5, Corrientes, República Argentina. CP 3400.

2 National Research Council of Argentina (CONICET); Godoy Cruz 2290, CABA, Argentina, C1425FQB.

${ }^{3}$ EDGE of Existence Affiliate Programme, Zoological Society of London (EDGE-ZSL); Regent's Park, London, England NW1 $4 \mathrm{RY}$

${ }^{4}$ Proyecto Quimilero, Misión Nueva Pompeya s/n; Chaco, Argentina. CP3705

${ }^{5}$ Prescott College, 220 Grove Ave, Prescott, AZ 86301, EE. UU.

${ }^{6}$ International Union for the Conservation of Nature (IUCN); Rue Mauverney 28

1196 Gland, Switzerland

${ }^{7}$ Group of Environment and Landscape Ecology (GEPAMA); Ciudad Universitaria, pab3, CABA, Argentina. CP1428.

Corresponding Author: Micaela Camino.
}

Institutional mailing address: CECOAL; kilometer 2.5 of the National Road N5; Corrientes; Argentina. CP3400. Telephone number: +54 911 6995-5917

* Corresponding author. $\square$ E-mail address: micaela_camino@hotmail.com; micaela.camino@gmail.com 


\section{INTRODUCTION}

Many societies have a close relationship with wildlife. Each culture has unique relations with wildlife, shaped by its perceptions, beliefs and cosmovision (Berkes 2012; Gadgil et al. 1993; Ingold 1986; St John et al. 2011). Although perceptions of wildlife being specific to each culture, there are general concepts that describe ways of perceiving wildlife common to many different human groups. Many indigenous societies perceive wildlife from an animistic view, i.e. humans and nonhuman beings hold inside an equal spiritual essence and the difference between them is based on their bodies, which allow different behaviours and social relations (Descola 2012; Viveiros de Castro 2013). The relation of a society with wildlife has many different dimensions, some are subtle, i.e. not obvious, impalpable and difficult to detect, e.g. spiritual (Alves et al. 2012). Other dimensions of societies' relations with wildlife are more obvious, e.g. using wild animals as a food source (Nasi et al. 2011; Ojasti and Dallmeier 2000).

Hunting to acquire wild meat (WM) and other goods, e.g. medicine, is a widespread activity around the globe (FAO 1998; Nasi et al. 2011; Ojasti and Dallmeier 2000; Silvius et al. 2004). Hunting is shaped by the representation system and the perceptions of the hunter and of the society he belongs to (Descola 1986; Ingold 1986, Medrano 2014). In fact, this practice contains a culture's representation system itself as the hunter follows explicit and implicit norms, uses certain techniques, prefers particular species, etc. (Ingold 1986; Descola 1986; Viveiros de Castro 2013). Thus, in addition to satisfying metabolic needs, hunting is a particular way in which each culture relates with nature and wild animals, and it operates in the practical and symbolic dimensions (Ingold 1986; Descola 1996; Viveiros de Castro 2013).

Hunting is also associated with a unique knowledge that societies accumulate and use to catch their prey. Societies that have been hunting across centuries usually hold Traditional Ecological Knowledge (TEK) associated with the biology and ecology of wild animals (Berkes 2012). This knowledge reveals the close relation of these societies with wildlife and with their environment (Berkes 2012; Prober et al. 2011). The TEK associated with wildlife is commonly the base for social-norms that guide sustainable hunting and habitat protection (Berkes et al. 2000, 2012; Fraser 2006, Gadgil et al. 1993). In American indigenous groups, TEK is usually combined with shamanic practices to regulate the relations with the environment, favouring sustainable practices (Cordeu and Siffredi 1971; Susnik 1985; Galinier et al. 1995).

Worldwide, populations of most wildlife species are declining (Barnosky et al. 2011; Ceballos et al. 2017). This affects most dimensions of the relations of humans with wildlife and it is particularly alarming for societies that depend on wildlife for nutrition (e.g. Altrichter 2006; FAO 1998; Nasi et al. 2011). These societies are usually poor, isolated, and practice subsistence hunting for survival, i.e. extraction of terrestrial vertebrates for trade or consumption (Nasi et al. 2011; Ojasti and Dallmeier 2000). Subsistence hunting is frequently unsustainable (e.g. Altrichter 2006; Peres 1996; Robinson and Bennett 2000) and therefore, poverty and wildlife overexploitation are usually combined problems (Barrett et al. 2011; Nasi et al. 2011). Solutions for these situations require an understanding of local contexts and the development of strategies based on the 
particular perceptions and interactions of each culture with the environment (Manfredo and Dayer 2004; St John et al. 2011).

In many areas of the Neotropics, rural indigenous people and mestizos live alongside in biodiversity-rich environments (Camino et al. 2016; Ojasti and Dellmeier 2000; Redford and Robinson 1987). Indigenous groups have an historical continuity with pre-settler societies while mestizos are descendants of Europeans that mixed with indigenous groups before nations conquered these territories (Altrichter 2006; Camino et al. 2016; Silvius et al. 2004; UN 2009). Indigenous and mestizo people have distinct cultures, they are minorities in the countries they inhabit and are usually strongly connected with nature and that practice subsistence hunting (Cáceres 2003; Silvius et al. 2004; UN 2009). Comparisons between these groups regarding their perceptions of and relations with wildlife are scarce. Few such comparisons have been carried out since Redford and Robinson (1987). More extensive comparative studies would facilitate more focused and adequate conservation measures when the two groups are found in the same spatial location.

The South American Chaco is a biodiverse and culturally rich ecoregion that covers over $10^{6} \mathrm{~km}^{2}$ (Bucher and Huszar 1999; Dinerstein 1995; Camino et al. 2016; Metraux 1946). Despite being a deforestation hotspot, large patches of continuous natural ecosystems remain (more detail in Study Area section; Hansen et al. 2013; Baumann et al. 2016). We worked in a portion of the Dry Chaco where these remaining patches of natural ecosystems are inhabited by indigenous Wichís and mestizos Criollos. These human groups share their territories and seem to be practicing unsustainable subsistence hunting (Altrichter 2006; Camino et al. 2016; Periago et al. 2014; Suárez 2012).

With the aim to contribute to the development of effective conservation actions in this area that incorporate the needs of both groups, we describe and compare Wichís and Criollo's perceptions of and relations with wildlife. We studied different aspects of these societies relationship with nature, including: (i) their perceptions of the importance of WM as a food resource, (ii) their hunting motivations, (iii) techniques, (iv) patterns and (v) the different uses they give to wildlife. Our hypotheses were that: (1) characteristics (iiv) are different in the Wichís and in the Criollos societies but (2) both groups have a close relation with wildlife. We analyse these cultures' perceptions of wildlife and their relations with wild animals, focusing on hunting and on their TEK. We discuss our results from a conservation perspective, suggesting management actions that are legitimate for each culture and that would help achieve the successful conservation of wildlife in the area.

\section{Human Groups: indigenous Wichís and mestizos Criollos}

Before the 20 $0^{\text {th }}$ Century, Wichís (are also known as Matacos) were nomads and followed fixed routes across the Central Chaco. Routes were associated with particular seasons of the year (Braunstein 1992; Cordeu and de los Ríos 1982; Metraux 1946). Their livelihood was based on hunting, gathering and fishing (Metraux 1946). Wichís considered that each species has a spirit that protects and owns it, i.e. owner (Braunstein 1992, 2005; Metraux 1946; Palmer 2005; Susnik 1985). Owners were considered powerful beings and hunting was regulated by norms and shamanic practices that looked to satisfy the 
owners' will and rules (Braunstein 1992, 2005; Cordeu and Siffredi 1971; Metraux 1946; Palmer 2005). The perceptions of wildlife of Wichís can be framed in animism: humans, animals and other beings share a will or soul, i.e. husek, in different degrees (Montani 2013; Palmer 2005).

In late $19^{\text {th }}$-early $20^{\text {th }}$ centuries, the Argentinean state entered the Dry Chaco region through military campaigns and Wichis were killed or used as slaves or cheap labour (Gordillo 1993; Rodriguez Mir 2016). A strong movement to convert people to christianity was already in place since the 1600 's and continued during this period (Palmer 2005; Rodriguez Mir 2016). Indigenous groups that survived settled in one place and were no longer nomadic, i.e. sedentarized (Gordillo 1993; Rodriguez Mir 2016).

Today, Wichís live in communities in marginalized and isolated areas that are very small compared to the areas that they used in the past (Gordillo 1993; Palmer 2005; Rodriguez Mir 2016). These areas were considered unproductive for large scale commercial agriculture until this decade (Gordillo 1993; Rodriguez Mir 2016). Many groups continue hunting, gathering and fishing, they also receive social government aid (Gordillo 1993; Rodriguez Mir 2016). Wichís traditional religious beliefs and cosmovision was modified in different degrees and thus, hunting-regulation is not always present (Arenas 2003; Cordeu and Siffredi 1971; Palmer 2005). Most Wichís practice a protestant christianity and show shamanic characteristics in their religious practices (Dasso 2010; Palmer 2005). Also, shamans are still present in some communities and their procedures have evangelical attributes (Dasso 2010; Palmer 2005; Scarpa 2009). Many Wichí groups consider that the owners left while others consider that these and other spirits are still present in different degrees (Barbarán 2000; Suárez 2012; Susnik 1985). Wichís maintain their identity and cosmology through their language (Palmer 2005). And although externally they lost traits of their traditional identity, some authors consider that their inner identity was consolidated after colonisation (Metraux 1946; Palmer 2005).

Criollos, also known as Creolos or Campesinos, are mestizos, i.e. descendants of the first Spanish colonisers that have mixed with indigenous groups since the $16^{\text {th }}$ century (Cáceres 2003; Dasso 2010). Criollos colonised the Dry Chaco during the $20^{\text {th }}$ century; they came from the neighbouring Provinces looking for grasslands to practice extensive cattle ranching (Dasso 2010). Criollos' cultural background is a mixture of the gauchos' culture, the first Spanish settlers, and the different indigenous cultures from the Andes and the Chaco region (Dasso 2010; Scarpa 2004). Criollos are catholic but in the Dry Chaco many became evangelist (Dasso 2010; Scarpa 2004). Criollos' beliefs and rituals have indigenous influences as they have been in contact with different indigenous groups since they entered the region (Dasso 2010; Scarpa 2009). Criollos and Wichís have exchanged religious practices, beliefs and oral traditions (Dasso 2010). Criollos have borrowed indigenous knowledge and their TEK is rich, at least regarding medicinal plants (Scarpa 2004, 2009).

Criollos practice extensive livestock ranching, mainly raising cows and goats (Dasso 2010; Gordillo 1993; Toledo and Trillo 2018). They also practice subsistence hunting and gathering. Many receive social government aid. The Criollos' productive land area is also the unique dwelling and the first source of food for the family (Cáceres 
2003; Toledo and Trillo 2018). Criollos generate or harvest their own food, they do not contribute to the national economic and productive system with stable labour, the main force of their productive unit is the family and they preserve traditional practices with little technological investment (Cáceres 2003; Dasso 2010; Toledo and Trillo 2018). Thus, Criollos preserve traditional practices and navigate the margins of the hegemonic capitalist economic-system (Toledo and Trillo 2018).

Wichís and Criollos disagreed and fought over land-tenure since Criollos entered the territory (Palmer 2005). Wichís perceive that Criollos occupied their lands and limited their nomadic movements and the availability of common natural resources (Palmer 2005). Criollos perceive that Wichís demand larger territories that what they need and use and that they are lazy (pers. obs.). Enmity between both human groups persists even though they share territories, beliefs and some characteristics in the way they live (Dasso 2010). Wichís and Criollos general behaviour is very different: Wichís live in communities of up to 30 houses and their manners are usually gentle, they do not usually raise their voice or use force when manipulating animals. On the other hand, Criollos live in small isolated family groups, Criollos like to show their force and can rudely manipulate cows or horses while Wichís find these behaviours aggressive and despicable (Dasso 2010; Toledo and Trillo 2018).

\section{MATERIAL AND METHODS}

\section{Study area}

We worked in a portion of the Dry Argentinean Chaco, in the Chaco Province where natural ecosystems remain (Figure 1).
These ecosystems are dominated by xerophytic forests of quebrachos (Schinopsisi lorentzeii and Aspidosperma quebracho-blanco) with patches of Bulnesia sarmientoi, Prosopis spp. and Ziziphus mistol (Morello et al. 2012). There are also bushlands and grasslands among other vegetation types (Baumann et al. 2016; Morello et al. 2012). The region experiences pronounced seasonality, with rain falling between 550 and $800 \mathrm{~mm}$ mainly between October and April (Morello et al. 2012). Summer temperatures can rise over $40^{\circ} \mathrm{C}$ while the winter is dry and can have temperatures below $0^{\circ} \mathrm{C}$ (Morello et al. 2012). The study area is inhabited by many species, including large vertebrates of high conservation value, e.g. chacoan peccary (Catagonus wagneri) or lowland Tapir (Tapirus terrestris; Altrichter 2006; Camino et al. 2016; Periago et al. 2014).

The study area is inhabited by indigenous Wichí and local mestizos, Criollos. The Wichís live in communities up to 30 houses spread throughout the forests (Palmer 2005). Inside the study area, there are 13 Wichí communities (Figure 1). The Criollos live and use the same areas as the Wichís but they do not share settlements (Scarpa 2004, 2009; Cáceres 2015). The Criollos inhabit small settlements spread throughout natural environments, most of which consist of one or two households although they may reach over 15 houses (Camino et al. 2016). There is no exact information about the number of Criollos' houses in the Dry Chaco (pers. obs.). There are a few villages in the study area, ranging between 20 and 1300 houses and inhabited by both socio-cultural groups

Intensive soy and, to a lesser degree, cattle production is expanding rapidly over these natural ecosystems (Baumann et al. 2016; Hansen et al. 2013; Morello y 
Rodriguez 2009). Intensive food production completely transforms natural ecosystems and threatens the long-term persistence of wildlife and of the region itself (Camba Sanz 2018; Morello and Rodriguez 2009; Periago 2014). Large vertebrate species may be rapidly disappearing of these ecosystems, where habitat loss is confining local societies and wildlife to areas where subsistence hunting may be unsustainable (Altrichter 2006; Camino et al. 2016; Periago et al. 2014).

\section{Field Data Collection}

Between November 2010 and August 2011 we conducted semi-structured interviews with heads of families (males between 17 and 72 years) from both the Wichís $(n=41)$ and Criollos $(n=64)$. We carried out between two and four interviews per settlement, depending on the size of the settlement. We surveyed the 13 Wichí communities in the study area (Figure 1). Using Google Earth (Google, Inc., Mountainview, CA, USA) and satellite images (Landsat 5) we estimated that there are 69 Criollo settlements in the study area and we randomly chose 35 of these settlements $(51 \%)$ to perform the interviews. In 4 of the 35 Criollo settlements we could not perform interviews because people did not want to participate $(n=2)$ and because we could not access the houses due to the bad condition of the roads $(n=2)$. We did not perform interviews in the villages because villager's may have different perceptions of and relations with wildlife than rural inhabitants (Altrichter 2006).

We conducted semi-structured interviews as informal conversations, covering a list of topics and questions (full details given in Appendix S1) which focused on determining:

i. Perception of the importance that WM has in their diet;

ii. Hunting motivations;

iii. Hunting techniques;

iv. Most hunted species in different periods of the year (hunting patterns);

v. Uses of wildlife (e.g. meat, utensils, etc.)

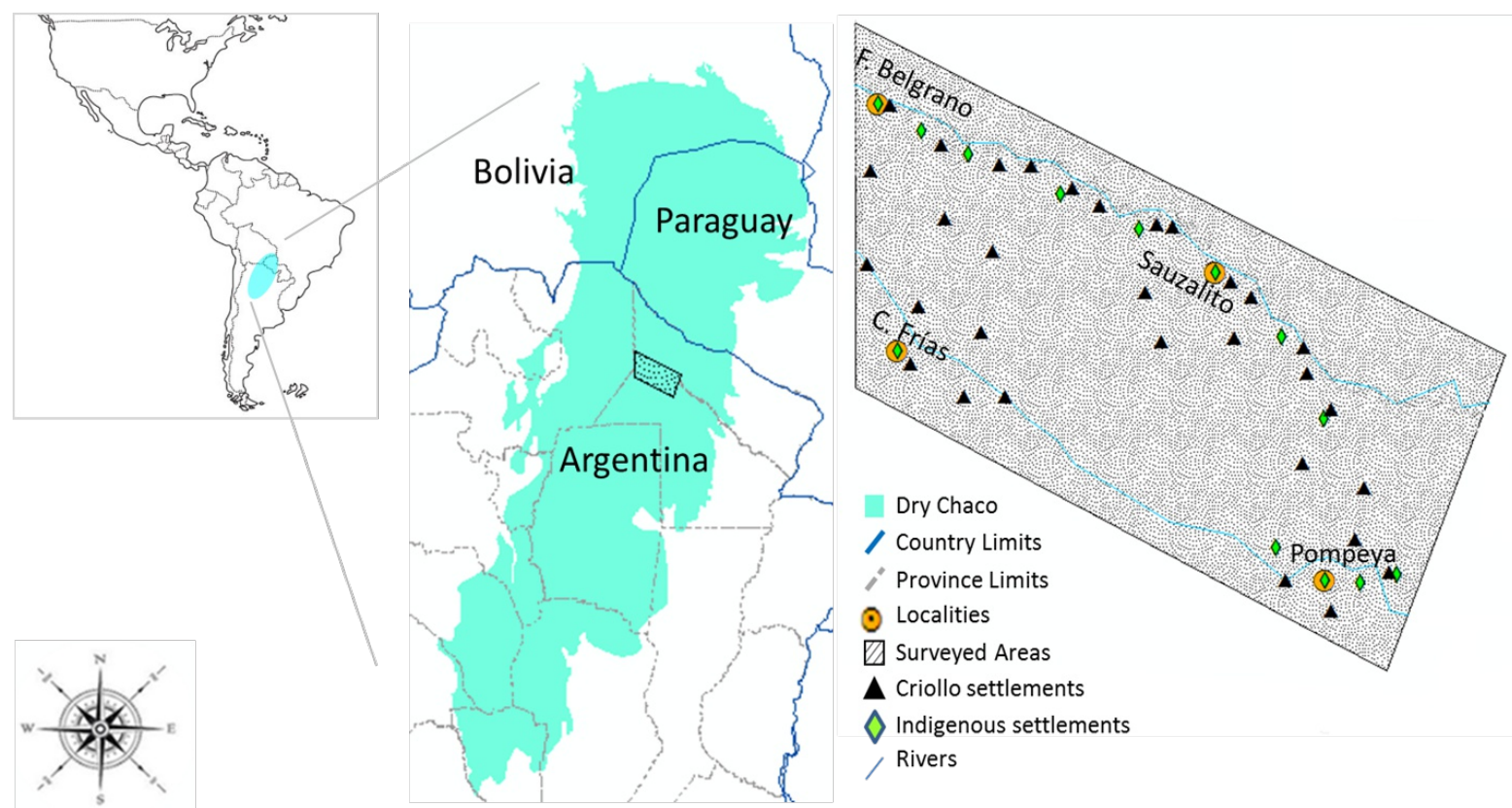

Figure 1. Study Area. 
Through semi-structured interviews we also intended to acquire a broader understanding of the relationship that these cultures have with wildlife and the local environment, including norms, beliefs and knowledge (Appendix S1). Interviews were conducted in Spanish and lasted between one and four hours.

We did 14 follow-up visits to interview Wichís and 19 to interviewed Criollos to review answers or complete information. When responses were ambiguous or uncertain we excluded them from the analysis. We chose this sampling design to cover a broad diversity of perceptions -a snowball sample design may have left aside geographically or socially isolated people. We interviewed only men because hunting is locally considered a male activity (Arenas 2003; Palmer 2005; Toledo and Trillo 2018). Also, many Wichí women of this area do not speak Spanish (pers. obs.). Interviewing only men may have limited our results.

Before the interview we explained our interests, the aim of our study, the procedures to carry out our study, the institutions we belonged to and how we were going to use and publish the information. We also informed local people about their right to decline our invitation to participate. Interviews only commenced when we had the verbal consent from the interviewee. Underage $(<18)$ respondents were only interviewed if their legal guardians also gave their consent. After explaining that our questions were for research purposes and that our aim was having a better understanding of the local reality, and after clarifying that we did not belong to any control agency, the interviewees answered questions about hunting without showing discomfort. During all interviews, we also conducted observations (Appendix S2).

In some settlements we performed unstructured interviews with key informants such as elders $(n=2)$ and government technicians $(n=2)$ to deepen our understanding on the above listed topics and the region's situation.

\section{Data Analysis}

With interviews and observations, we collected qualitative data and used it to describe perceptions, beliefs and practices associated with the topics of our study (i-v).

We also used quantitative analysis (for topics i, ii, iv and v): we coded and categorized the responses we received for different questions and calculated the percentage of respondents in each category. We analysed Wichís and Criollos data separately. To address the perceived importance of WM (i), we determined the percentage of Wichí and of Criollo respondents that consume WM, the percentage that consider it essential for their nutrition and the percentage that have access to other sources of meat. This last question was also associated to (ii) hunting motivations. To determine the (iv) most hunted species, we calculated the percentage of hunters of each group that hunt each species in each season. We also categorized the most common uses of wildlife and the percent of Wichís and Criollos that give these uses to wildlife (v).

To test if Wichís and Criollos differ in the analysed characteristics (i-v) we used qualitative information. For topics (i, ii, iv and v) we also determined if the number of Wichí and Criollo was significantly different using Chi-square test. When the number of respondents in one or more categories was $\leq 5$ we used Fisher's exact test instead.

To determine if Wichís and Criollos have a close relation with wildlife, we used qualitative and quantitative information 
regarding uses of wildlife. We also checked if TEK and hunting norms were present in these cultures.

\section{RESULTS}

\section{Importance of WM as a food resource and motivations for hunting}

Most Wichí (88\%) and Criollo (69\%) respondents consumed WM and their primary motivation for hunting was meat acquirement. However, their perceptions of the importance of WM in their diets differed $\left(x^{2}=18.7, \quad d f=1, \quad p<0.005\right)$ : only $35 \%$ of Criollos considered WM essential for their nutrition compared to $81.5 \%$ of Wichís. The Criollos expressed that their need for meat is greater during the last 2 months of the dry season, when they perceive their livestock to be thin and inedible. On the other hand, the Wichís considered that without hunting, meat consumption would be 12 days/month (average) and that this was deemed insufficient for proper nutrition.

The two groups also differed in how they could access meat. Most Wichís (94\%) did not have domestic cattle and those who did, raised goats more as pets than as animals that provide economic benefits. Wichís -with or without goats- purchased meat in town with money they or their relatives earned through temporary jobs, e.g. building work, or social plans. When they did not have more cash, access to meat depended on hunting and, for some, on fishing. All Wichí hunters reported that they only hunt when they do not have access to meat and that they share WM with other families in their communities. Thus, only $66 \%$ of Wichís that consumed WM practiced hunting. Wichís considered that how much they hunt is influenced by the number of people with whom they share meat $(91 \%)$, the income the family has (19\%) and the community they belong to $(18 \%)$.

Criollos, on the other hand, raised domestic livestock and hunted even if they had animals to slaughter (66\%). $95 \%$ of Criollos consumed WM in their own household, and meat was not shared with the community. Criollos indicated that when they find a prey they may leave it, hunt it, or return the day after. This decision was reported to depend on different interrelated factors: (i) the particular species detected and how palatable they consider it; (ii) the condition of cattle (e.g. cattle are thin and weak during the dry season and thus domestic meat availability is low, so hunting is a profitable activity); (iii) the reason for walking (e.g. they may have been looking after a new-born calf, a priority over hunting); (iv) the dogs they have, e.g. if they find collared peccary (Pecari tajacu) and do not have specialized dogs, then they do not hunt them); (v) distance to the house. Most Criollo respondents $(95 \%)$ considered that factors (i) and (ii) are directly related to seasonality and that wild species' availability changes throughout the year. $98 \%$ of Criollos also perceived that cattle condition similarly changes seasonally.

Although Criollos reported that their main motivation for hunting was meat acquirement, $88 \%$ admitted hunting pumas (Puma concolor) with the aim of eliminating the species. This is because pumas prey on the goats, pigs, young horses or cows. During the interviews, Criollos referred to pumas using adjectives such as mean, ungrateful and miserly. Wichís showed no desire of eliminating pumas or any other wild species. Wichís did not describe pumas in any particular way but they did refer sometimes to jaguars as other human beings. 


\section{Hunting techniques}

Hunting techniques differed between the two socio-cultural groups. The Wichís who practice hunting are specific members of their communities known as mariscadores. Mariscadores go out hunting to places that have their own names and are known by the mariscadores of all clans in a $30-\mathrm{km}$ radius from the hunting sites. Most hunting areas are separated from the communities, not populated by humans and cannot be identified by any particular characteristic. Mariscadores pick in advance the area where they will go hunting, but not the species they will hunt. Mariscadores may hunt individually or in groups, depending on the clan they belong to. Although some mariscadores use guns sporadically $(\mathrm{N}=21$; $9.5 \%)$, most of them use clubs or slingshots and dogs that are not trained to hunt particular prey but help in detecting and catching wild animals. All Wichís indicated that traditionally, the mariscadores would visit a shaman before hunting and this shaman would then inform the mariscador if hunting of a particular species was permitted for him that day and the number of individuals they were allowed to hunt. The shamans would communicate with spirits that own and protect the game through specific rituals. Wichís reported that shamans are no longer present this area and hunters no longer perform these hunting rituals.

Conversely, Criollo hunters are normally opportunistic and rarely go out specifically to hunt. As extensive ranchers, they herd their cattle walking every day between 2 and 10 $\mathrm{km}$ through natural environments that surround their houses. During this activity, prey is sometimes detected with dogs helping detect prey. Most Criollos practice hunting and hunt alone (67\%), using specialized dogs and guns. Those who did not hunt alonestated they hunt with friends, family or neighbours.

\section{Hunted species}

The most frequently hunted species were the same for both groups with three exceptions (Table 1). Wichís hunt a larger number of species than Criollos (27 and 19 species respectively and see others in Table 1). Wichís and Criollos are opportunistic

Table 1. Percent of Wichís $(\mathrm{N}=18)$ and Criollos $(\mathrm{N}=40)$ that hunt each species or group of species. $\left({ }^{*}\right)$ denotes a significant difference $(p<0.005)$ in the number of hunters of each socio-cultural groups that catch each species or group of species, analysed using Chi-square $\left(X^{2} ; \mathrm{df}=1\right)$ or Fisher's exact test (F) on raw counts.

\begin{tabular}{l|l|l|l}
\hline & \% Wichi & \% Criollo & $\mathrm{X}^{2} / \mathrm{F}$ \\
\hline Armadillos & 61 & 58 & $\mathrm{X}^{2}=0.8$ \\
\hline Peccaries & 6 & 43 & $\mathrm{~F}$ \\
\hline Grey brocket deer (Mazama guazoubira) & 11 & 45 & $\mathrm{~F}$ \\
\hline Plains viscacha (Lagostomus maximus) & 50 & 50 & $\mathrm{X}^{2} \sim 0.0$ \\
\hline Chacoan cavy (Pediolagus salinicola) & 67 & 60 & $\mathrm{X}^{2}=2.7$ \\
\hline Chaco chachalaca (Ortalis canicollis) & 78 & 65 & $\mathrm{~F}$ \\
\hline Tegu lizard (Tupinampis spp) & 61 & 40 & $\mathrm{X}^{2}=27.5$ \\
\hline Others & 50 & 13 & $\mathrm{~F}$ \\
\hline
\end{tabular}


hunters but Criollos do look for certain species. Criollos' most frequently sought species, in order of preference, were chaco chacalaca (Ortalis canicollis), chacoan cavy (Pediolagus salinicola) and southern threebanded armadillo (Tolypeutes matacus). Other armadillo species that are not specially sought but killed if the opportunity exists are (in order of preference): Chaetophractus vellerosus, C. villosus, Euphractus sexcinctus, Dasiphus novencinctus, $D$. sexcinctus and Cabassous chacoensis. All respondents of both groups expressed their preference for fat individuals when hunting. And even when consuming beef or other domestic animals, individuals with more fat are preferred.

There are species that both Wichis and Criollos consider unpalatable and never eat, e.g. giant anteater (Myrmecophaga tridactyla). Wichís also had rules regarding the consumption of certain species, e.g. pregnant women should not eat plains viscachas (Lagostomus maximus). Although all Wichís know this rule, they do not follow it because of considering it "old". Another rule, stated by all Wichí and Criollo hunters, was that pregnant or breeding females of any species should not be hunted. However, most Wichí (68\%) and Criollo (78\%) hunters admitted to hunting pregnant or breeding females and said their dogs were to blame. They also blamed the other socio-cultural group of not respecting this norm.

All respondents of both socio-cultural groups perceive three seasons according to weather characteristics (e.g. rainfall), the most frequently hunted species and the behaviour of wildlife. These seasons are: dry (July-September), wet (October-February) and "temporal" (March-June). Wichí and Criollo describe temporal as the season when misty rain falls during many successive days, the ground remains wet and it is mostly overcast. Another description they provide is that temporal is the season when armadillos Tolypeutes matacus conduct courtship behaviour. Locally hunted and consumed species change with the seasons (Figure 2). In both socio-cultural groups, armadillos are hunted most during the temporal season (Figure 2). The species is also hunted in the wet season (Figure 2) although both Wichí and Criollo hunters said this should not be done because armadillos are thin in this season. The tegu lizard (Tupinampis spp.) is almost exclusively hunted during the wet season (Figure 2). The proportion of Criollos hunting grey brocket deer and peccaries decreases during the wet season (Figure 2). The proportion of Wichís who hunt these species is low and we did not evaluate changes through the year.

The Chacoan cavy was hunted by a large number of interviewees along the year without significant fluctuations (Figure 2). The proportion of people hunting plains viscacha and chaco chacalaca showed some seasonal fluctuations, and these changes differed between Wichís and Criollos (Figure 2).

\section{Other uses of wildlife}

Many interviewees use the appearance or sight of some species as a predictor or indicator of a future event (Figure 3). Wichís stated that they use the appearance or sight of some wild animal species as predictors or indicators. However, Wichí respondents were reluctant to respond which particular species they use as predictors or indicators, and which events these species were related to. One Wichí respondent said that although there are many animals that indicate that something is happening or will happen, there are other beings, ahot or spirits, that do not 


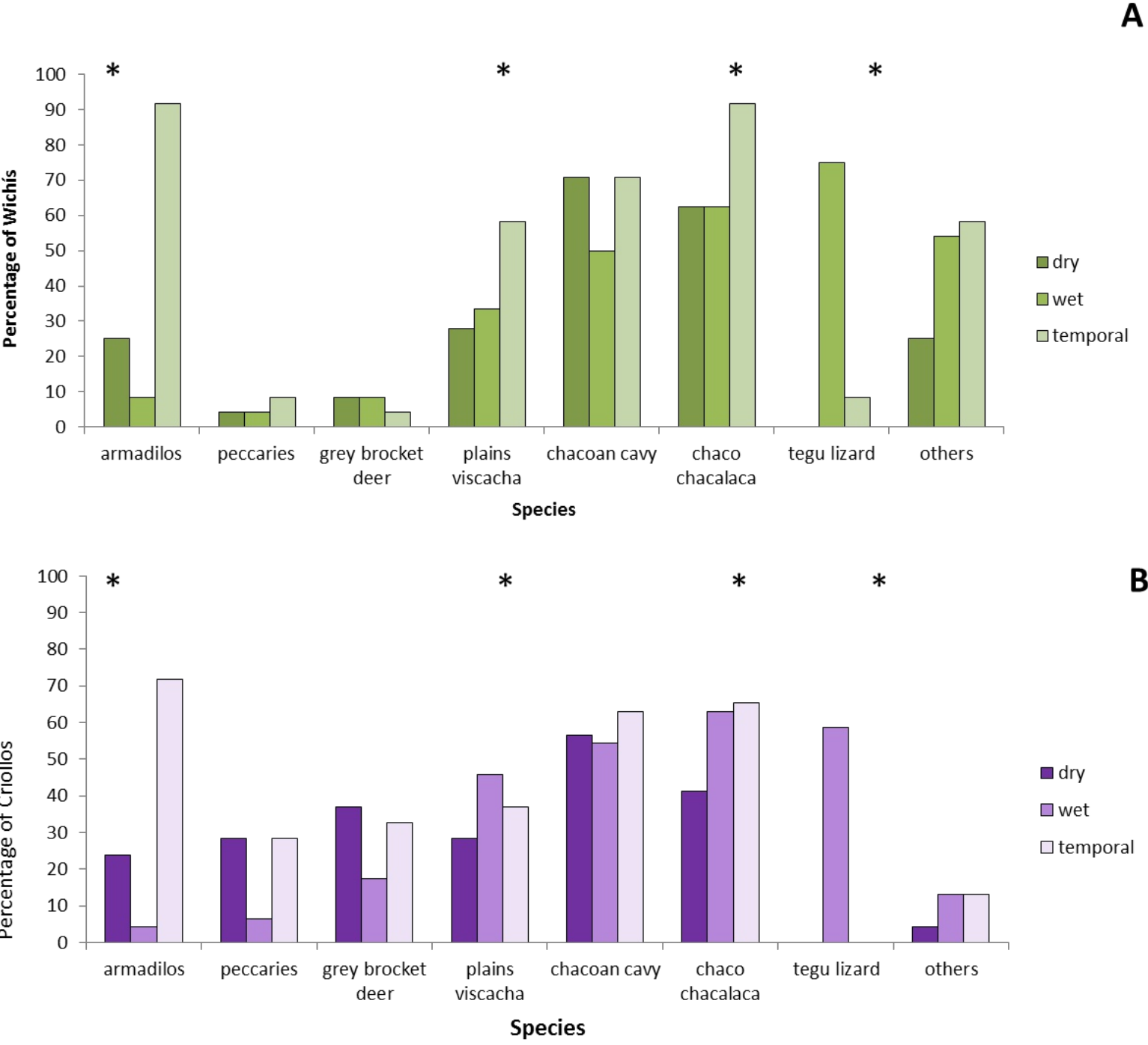

Figure 2. Seasonal changes in wild species hunting. (A) Wichí $(\mathrm{N}=18)$, (B) Criollo $(\mathrm{N}=40)$. $\left(^{*}\right)$ Significant difference in the number of hunters when comparing seasons, Fisher's exact test, $p<0.01$.

follow our western society's logic, and that are better indicators than wildlife species. Other three respondents referred to owners that, when seen in the forest, indicate that that person should not enter that area again. They also referred to the viborón, a spirit closely related to the lampalagua (Boa constrictor occidentalis) that indicates that the Bermejo River will grow.

Criollos also use wildlife species as indicators or predictors and they were not unenthusiastic to answer our questions regarding this topic. Most of the species they use are birds. Birds indicate weather conditions: rain, high temperatures, drought period starting or ending; birds also indicate time of the day and of the year, a persons' arrival to the house, death or marriage and other meanings. Criollos also consider that: (1) the appearance of tapirs (Tapirus terrestris) indicates the beginning of a drought period; (2) the appearance of tortoises indicates bad luck; (3) the presence of chacoan peccary in a forest indicates that it is well preserved (they referred to well preserved forests as silent forest) and that 
(4) when caimans (Caiman spp.) are present in a pond, water will remain across the year.

Respondents of both groups use some species for medicinal purposes (Figure 3). The most commonly reported medicine was the fat of puma, alligator or tegu lizards, which is used to alleviate bruises and respiratory problems. The giant anteaters' fat was also used as a medicine and Criollos also used its fur to make ropes. The tapir's fur was used by some Criollos for making ropes without any treatment, while giant anteaters' is always previously braided. Criollos also use some species as pets, e.g. peccaries, grey brocket deer, armadillos, geoffroy's cat's (Leopardus geoffroyi) and small anteaters (Tamandua tetradactyla). Also, many Criollos had parts of wild animals as ornaments in their houses (Figure 3), e.g. geoffroy's cats' fur, skulls of peccaries and grey brocket deer. No Wichí respondent expressed these uses and neither did we observe them when visiting their houses (Figure 3).

Another relation with wildlife was in the spiritual dimension. 94\% of Wichís reported that animals have a spiritual component besides the physical one. Both groups expressed that they believe in the existence of spirits that own and protect wildlife species. Wichís related to these spirits through shamans in the past but this practice is now reported to be lost. Criollos did not historically have shamans but $80 \%$ of them reported the existence of spirits that protect and own wild animals and that a hunter can see these spirits when overhunting a species, as a signal to the hunter to stop.

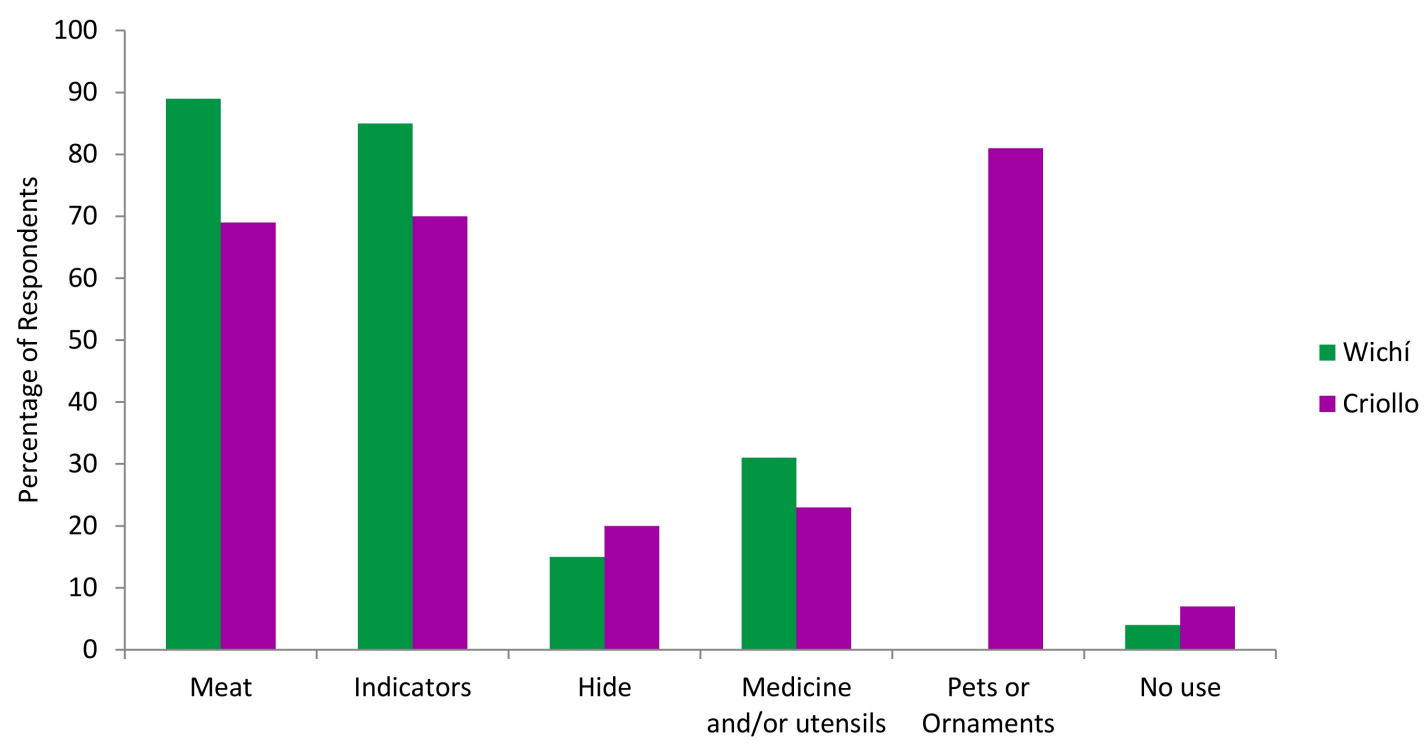

Figure 3. Percent of respondents of each socio-cultural group and the different uses they reported for wildlife. $\left({ }^{*}\right)$ Significant difference in the number of Wichís and the number of Criollos that use wildlife species as Pets or Ornaments. 


\section{DISCUSSION}

Indigenous Wichís and mestizos Criollos of the Dry Chaco have distinctive perceptions and relations with nature, consistent with their unique cultures and livelihoods. Wichís and Criollos practice subsistence hunting with seasonal changes and the main purpose of their hunting is meat acquirement. Both groups also coincide in their preference for hunting and consuming animals with fat, and in using fat of different species as medicine. Other Wichí communities also preferred fatty individuals and used fat as medicine (Arenas 2003). Qom and Mocoví indigenous groups, also found in the Chaco ecoregion, also showed this preference (Medrano 2014). For the Qom, consuming fat and using it as medicine was associated with the incorporation of the power of the dead animal (Medrano 2014). In the past, most Chaquenian indigenous groups considered that consuming a wild animal implied acquiring its' characteristics (Metraux 1946). Further research could clarify if the preference and use of fat by Wichís and Criollos indicates a present belief of power acquisition.

Wichís and Criollos also coincide in the species they hunt the most, with some exceptions. Wichís rarely hunt large species probably because they do not usually have guns or trained dogs. Our results differ from previous studies, where Wichí hunters used fire guns and trained dogs to hunt peccaries and other large terrestrial vertebrates (Barbarán 2000; Metraux 1946). A possible explanation for this difference is the history ofland-tenure conflicts between these groups in our study area. Although Wichís and Criollos share a territory, there are areas dominated by one or the other human group. Large terrestrial vertebrates use large areas and when hunting them, Wichís may need to enter territories dominated by Criollos. Wichis always try to avoid direct confrontation and conflicts (Palmer 2005). Thus, it is possible that Wichís do not currently hunt these species in order to avoid confrontation.

Besides some differences in the species they hunt the most, Wichís and Criollos also differ in their perceptions of the importance of WM in their diets and in their hunting drivers and techniques. The differences between the two human groups seem associated with: (a) the sources and availability of animal protein within each socio-cultural group; (b) their differing social structure: Wichís live in communities and traditionally share harvested products -including WM- through mechanisms of general reciprocity (Rodriguez Mir 2016) while Criollos' social-lives are isolated (Dasso 2010; Toledo and Trillo 2018) and they consume WM within their own household.

Despite their differences, both Wichí and Criollo people have a close relation with wildlife. This is evident in the variety of ways that both groups use wild animals, including their use as food and medicinal resource and as indicators. Although we list some indicators and predictors associated to the symbolism and meanings given to wild species by these cultures, further research could provide more information. Wichís did not want to answer detailed questions about this topic. Owners and other spirits -ahotseem to be related to indications and predictions about nature and future situations. There is a chance that Christian institutions and past evangelization processes have prohibited the expressions of this knowledge. Another possible explanation is that they do not want to share this knowledge because they do not want to 
offend the ahot related with it. The relation of both Wichis and Criollos with wild animals is also present in a spiritual dimension: they consider that species owners are present and that there are paths to connect with these spirits. Although Wichís and Criollos define themselves as Christians, these are animistic beliefs.

According to our results, traditional animistic and shamanic cosmovision seem to persist in Wichí society and are also present in Criollos' perceptions and representations of reality. Both human groups referred to animal owners. Wichís described jaguars as other humans and as beings that own a husek, i.e. a soul or will (Camino et al. 2016). To some degree, Wichís present perceptions agree with perspectivism, i.e. humanity and the human soul is the common background of existence of humans and animals and each species sees itself as human (Viveiros de Castro 2013). In the case of Criollos, animistic beliefs are also reflected in the adjectives they use to refer to pumas. By describing animals with human traits and personalities, frontiers that separate humans and animals become imprecise (Medrano 2014). Criollos' are relating with wildlife, or at least with pumas, based on social and ideological institutions that organise their own symbolic universe. Criollos' perceptions of relations with wildlife are framed in a sociocosmological conception and reality representation similar to that of Chaquenian indigenous groups (Medrano 2014).

The close relation that Wichis and Criollos maintain with wildlife and nature is also demonstrated by these groups' TEK and hunting-norms. Opposed to scientific classification (sensu Morello et al. 2012), members of both socio-cultural groups differentiate three seasons. These three seasons also differ to the Wichís' traditional characterisation of the year: an annual cycle of four seasons (Barúa 2004; Palmer 2005). However, the three-season year characterization may always have been present in indigenous knowledge. We believe that the three-season classification is more evident in the present because it is more useful than in the past. Firstly, because Wichís are now sedentary and the fourseason year cycle was associated with Wichís' traditional cosmology and with their nomadic movements (Barúa 2004). Second, because the three-season cycle relates seasonal patterns with animal ecologies, which are the base of hunting norms that aim to secure food supply. Norms associated with sustainable use of resources and TEK are found in many other societies worldwide and reveal an intimate relation between local cultures and nature (Fraser et al. 2006; Prober et al. 2011).

Social-norms based on TEK could be a tool to prevent overexploitation of wildlife (Berkes et al. 2000; Fraser et al. 2006; Gadgil et al. 1993). Yet, most Wichí and Criollo hunters are breaking these norms. This could be related to a TEK crisis, i.e. a decline in the transferal or uptake of local TEK. The breaking of norms could also be explained by a hypothesis proposed by Arenas (2003) and Suárez (2012): Wichís have always taken from nature all the resources they need and they have always broken their social-norms even if there was punishment. We do not consider this hypothesis very plausible because Wichís' traditionally feared the ahot, spirits among which are the animal and forest owners (Braunstein 1992, 2005; Palmer 2005; Suarez 2012). In Wichís' traditional cosmovision, the ahot are the main cause of otherness, i.e. a state where humans are no longer humans and that threatens the individual and the society (Metraux 1946; 
Palmer 2005). Wichís avoid otherness with an extremely cautious behaviour (Cordeu and de los Ríos 1982; Palmer 2005). Breaking hunting norms does not correspond with Wichís typical cautious behaviour.

Hunting is shaped by cultural traits but it is also conditioned by past and present political and economic characteristics and dynamics (Gordillo 1993). Thus, a third explanation of why Wichís and Criollos are breaking hunting norms is the social, economic and political abuse that these societies are experiencing under the Argentinean government and the capitalist productive-system (Gordillo 1993; Rodriguez Mir 2016). Both Wichís and Criollos' productive-systems differ to the hegemonic capitalist system and consequently, they are economically excluded (Cáceres 2003; Gordillo 1993; Rodriguez Mir 2016; Toledo and Trillo 2018). Also, Wichís and Criollos legal rights are usually violated (Dasso 2010; Palmer 2005; Rodriguez Mir 2016). Under economic and legal marginalization, an individual -and a society- may not be able to follow rules that reduce his/her chance of ingesting food. Additionally, these human groups usually have precarious land tenure (Cáceres 2015), a situation that increases the probabilities of natural resources overexploitation (Altrichter and Basurto 2008).

Whatever the reasons why Wichís and Criollos are breaking hunting-norms, the result is an increase in the probability of unsustainability of hunting. For Wichís, the absence of shamans may aggravate the situation. According to our results, shamans were a social institution that combined with TEK and norms to maintain the equilibrium with nature. They communicated with the owners and prescribed the species and number of individuals a hunter could harvest.
Our results coincide with Metraux (1946), Palmer (2005) and Galinier et al. (1995), and contradict the idea that Wichí norms and shamanic practices did not limit the number of harvested individuals (Barbarán 2000). In the present, it is highly probable that there are some species being unsustainably hunted, e.g. peccaries (Altrichter 2006; Camino et al. 2016). Overhunting combined with the high deforestation rates of the Dry Chaco mean wildlife species may fast be disappearing out of the region (Camino et al. 2016; Periago et al. 2014). This threatens wildlife species as well as Wichís' and Criollos' existence: previous wildlife extinctions in Chaco already caused the disappearance of other human groups, e.g. Pilagá groups (Metraux 1946).

Deforestation has started in a large area of the Dry Chaco but large patches of natural ecosystems remain (Baumann et al. 2016; Hansen et al. 2013). As wildlife species and their habitats are still present, successful management and sustainable hunting may still be possible. And even if hunting-norms are not fully adhered to, they are associated with local perceptions and may therefore be the base for effective conservation measures (Prober et al. 2011; St John et al. 2011). Conservation measures that are consistent with local seasonal changes and aligned to local norms and beliefs will be easier to implement and more likely to succeed.

\section{Conservation recommendations for Wichís and Criollos of the Dry Argentinean Chaco}

Conservation measures will benefit from considering the unique perceptions and beliefs of Wichís and Criollos. Existing hunting-norms and animistic beliefs could be used as a basis for conservation actions for both socio-cultural groups. Nevertheless, 
further research on these topics is required and we recommend the participation of anthropologists when designing and applying conservation measures in the Dry Chaco. Based on the similarities of the perceptions, beliefs and relations with wildlife and nature of the Wichís and Criollos, there are conservation measures that could be appropriate for both groups. Among these we recommend: (1) working on conserving and locally discouraging the hunt of armadillos when these are thin; (2) a local awareness and educational programme focused on conserving pregnant and breeding females of all species. If applying awareness and educational programmes, we also recommend that (3) these include information on how to manage dogs. Information about how to train and look after dogs should be provided to both groups because most people blame their dogs for killing non-target prey.

For Criollos, these programmes should also include information about the importance of pumas for conserving local ecosystems (Quiroga et al. 2016). Most Criollos hunt pumas with the aim of locally extinguishing the species but they do not know the ecological roles of this species. Criollos are also unaware that the density of pumas is low in this territory (Quiroga et al. 2016). The information about pumas should be targeted at the Criollos and the education and awareness programme should be applied simultaneously with: (a) measures to decrease the attacks of pumas on Criollos' livestock. If not, the measure would probably be insufficient. (b) An anthropological approach that aims to change the social relationship that Criollos have with pumas.

Both Criollos and Wichís believe that when their livelihoods improve, they hunt less. Criollos prioritize extensive ranching over hunting so they state that when they can focus on this activity, the time spent on hunting decreases. Wichís reported they used to hunt more before receiving social plans and that their hunting is associated with income. The truth of these affirmations is supported by the comparison of our results and those of a study developed in the late 1990's (Barbarán 2000). In the 1990's Criollos did not have government social aid or support for cattle and goat ranching, and they hunted every day (Barbarán 2000). During our study, Criollos had government support and hunted less than in Barbarán's research (2000), e.g. during our study the Social Development Ministry provided veterinary clinics. Therefore, measures that improve local livelihoods could have positive impacts on wildlife. However, for these measures to be effective, they should be part of a larger conservation and sustainable use plan, and local inhabitants should be included in the governance of their natural resources (Barbarán 2000; Bitanyi et al. 2012; Persha et al. 2011; Teel et al. 2007). Improvement of Criollos' livelihoods could include actions for a more efficient livestock production. This measure would have additional benefits: (a) alleviating habitat degradation due sub-optimal extensive ranching (Morello et al. 2012), and (b) decrease the attacks of pumas on Criollos' livestock (Quiroga et al. 2016). There are other ways of alleviating conflicts between extensive ranchers and wild carnivores, e.g. economic compensation for livestock loses (Gallardo et al. 2009). However, as the Criollos have a different logic and perception of pumas compared to the western society, these other alternatives are more difficult to apply and require further anthropological research.

For Wichís, it is not clear how to improve their livelihoods because their sense of economic well-being is not framed in the 
western perception of productivity (Gordillo 1993; Palmer 2005). We recommend the maintenance or increase of social aid for these societies and further research on their perceptions of production and of improvement of economic well-being. It is highly probable that Wichís need larger territories to sustain their hunting and gathering activities. This observation coincides with results of etnographical research (Palmer 2005). We agree with Barbarán's recommendation of a comprehensive ecosystem management that looks for the sustainable exploitation of its resources (Barbarán 2000).

According to our results, there are differences inside each human group, e.g. Wichis of this area never eat the giant anteater but Wichís of other areas within the Dry Chaco do consume this species (Arenas 2003). Another example: most Criollos believe that wildlife is not essential for their nutrition but others have the opposite perception of this. Considering the diversity within Wichís and Criollos societies will also faciliate more focused and effective conservation actions (Bitanyi et al. 2012; Brechin et al. 2002; Treves et al. 2009). Managers and researchers should consider that information available about Wichís and Criollos may not be true for all areas of the Dry Chaco. Other researchers already noticed a high diversity between Wichí groups in different cultural traits (Palmer 2005). Taking into account heterogeneity within groups of the same society will increase probability of success of conservation measures (Dahal et al. 2014).

Finally, we also encourage managers and land-use planners to consider that Wichís hunt in unpopulated areas. For them, these areas are important places to acquire a food resource which they consider vital. These areas are recognized only by specific members of the Wichí communities and they cannot be predicted by any particular characteristic. Therefore, before deciding land-uses and management actions, managers and planners in the Dry Chaco should always carefully address for this and other cryptic land-uses.

\section{CONCLUSION}

The accelerated loss of wildlife species in the world (Barnosky et al. 2011; Ceballos et al. 2017), besides having obvious negative effects on the biodiversity, threatens all the dimensions of the relations that humans have with wildlife. It is particularly worrying the threat that this situation poses to the food security of the many societies who depend partially or completely on subsistence hunting. Conservation measures to solve these situations are more effective when based on local inhabitant's perceptions of and relations with wildlife (Manfredo and Dayer 2004; St John et al. 2011). There are areas occupied by more than a socio-cultural group, e.g. in many areas of the Neotropics coexist indigenous and mestizo peoples. These groups may have close relations with wildlife and there may be similitudes in these relations, in their TEKs and in their perceptions of wildlife. These similarities can be the basis of general conservation measures for these areas. However, differences between ethnic groups that share a territory may also exist. The fact that different cultural backgrounds engender different perceptions of and relations with wildlife supports the idea that different cultures may need alternate approaches and actions for conserving wildlife, even when sharing the same territories.

For Wichís and Criollos of this area of the Dry Chaco we propose conservation 
measures grounded on their TEK and hunting norms. For both groups we recommend (1) discourage the hunt of thin armadillos and develop conservation measures focused on conserving them, (2) developing a local awareness and educational programme focused on conserving pregnant and breeding females of all species and (3) another one focused on how to manage dogs for them not to kill unwanted preys. We also suggest improving local livelihoods and research on Wichís' needs for economic well-being. For Criollos, we also recommend management and anthropological research to decrease the attacks of pumas on Criollos' livestock.

\section{ACKNOWLEDGEMENTS}

This research was financially supported by Progetto Güembé, the National Agency of Science (PICT 2450) and the University of Buenos Aires. We thank the support of the Group of Environment and Landscape Ecology (www.gepama.com.ar); local inhabitants of the Dry Argentinean Chaco for sharing their time and knowledge with us. Thanks to REDAF, Prof. J.H. Morello for his support and inspiration; M.L. Pizzi, H.H. Córdoba, A. Kees, G. Insaurralde, A. Silva and N. Fleita-Zain for their logistical support; and the Chaco Province for the permissions. And thanks to reviewers for their interesting comments and for helping us in giving the article an interesting perspective. Thanks to C.Gray and C.Murray, biologist and social scientists of ZSL (Zoological Society of London, UK), for their useful comments and for correcting our English; and also to Rachel Kemp for checking our English.

\section{REFERENCES}

Altrichter M (2006) Wildlife in the life of local people of the semi-arid Argentine Chaco. Biodiversity and Conservation 15:2719-2736.

Altrichter M, Basurto X (2008) Effects of Land Privatisation on the Use of Common-pool Resources of Varying Mobility in the Argentine Chaco. Conservation and Society 6:154-65.

Alves RR, Rosa IL, Neto NAL, Voeks R (2012) Animals for the gods: magical and religious faunal use and trade in Brazil. Human Ecology 40 (5):751-780.

Arenas P (2003) Ethnography and diet of the toba-ñachilamoleek y wichí-lhuku'tas of Chaco (in Spanish). Authors'edition, Buenos Aires, Argentina.

Barnosky AD, Matzke N, Tomiya S, Wogan GOU, Swartz B, Quental TB, Marshall C, McGuire JL, et al. (2011) Has the Earth's sixth mass extinction already arrived? Nature 471: 51-57.

Barrett CB, Travis AJ, Dasgupta P (2011) On biodiversity conservation and poverty traps. Proceedings of the National Academy of Sciences 108(34): 13907-13912.

Barbarán FR (2000) Recursos alimenticios derivados de la caza, pesca y recolección de los Wichi del Río Pilcomayo (Provincia de Salta, Argentina). Manejo de Fauna Silvestre en Amazonia y Latinoamérica. CITES Paraguay-Fundación Moisés Bertoni-University of Florida. Asunción, Paraguay: 507-527.

Barúa G (2004). Lo "eterno" y lo "fugaz": el ritual del yatchep entre los wichí bazaneros. Archivos, Departamento de Antropología Cultural del CIAFIC 2: 181-206

Baumann M, Gasparri I, Piquer-Rodríguez M, Gavier Pizarro G, Griffiths P, Hostert P, Kuemmerle $T$ (2017) Carbon emissions from agricultural expansion and intensification in the Chaco. Global change biology 23(5): 19021916.

Berkes F, Colding J, Folke C (2000) Rediscovery of traditional ecological knowledge as adaptive management. Ecological Applications 10(5): 1251-1262.

Berkes F (2012) Sacred Ecology. 3rd Edition. Routledge - Taylor and Francis, New York, USA. 
Bitanyi S, Nesje M, Kusiluka LJ, Chenyambuga SW, Kaltenborn BP (2012) Awareness and perceptions of local people about wildlife hunting in western Serengeti communities. Tropical Conservation Science 5(2): 208-224.

Braunstein JA (1992) Presentación. In Braunstein JA (ed) Hacia una carta étnica del Gran Chaco. Centro del Hombre Antiguo Chaqueño, Las Lomitas, Formosa, Argentina.

Braunstein JA (2005) Los pueblos indígenas del Gran Chaco. Mundo de Antes 4:127-137.

Brechin SR, Wilhusen PR, Fortwangler CL, West PC (2002) Beyond the square wheel: toward a more comprehensive understanding of biodiversity conservation as social and political process. Society and Natural Resources 15: 41-64

Bucher EH, Huszar PC (1999) Sustainable management of the Gran Chaco of South America: ecological promise and economic constraints. Journal of Environmental Management 57: 99-108.

Cahoone L (2009) Hunting as a Moral Good. Environmental Values 18: 67-89.

Camino M, Cortez S, Cerezo A, Altrichter M (2016) Wildlife conservation, perceptions of different co-existing cultures. International Journal of Conservation Science 7(1): 109-122.

Cáceres D (2003) El campesinado contemporáneo en la República Argentina. In: Thornton $\mathrm{R}$ and Cimadevilla $\mathrm{G}$ (eds) La extensión rural en debate. Concepciones, retrospectivas, cambios y estrategias para el Mercosur. INTA, Buenos Aires, Argentina. 173$197 \mathrm{pp}$.

Cáceres DM (2015) Accumulation by dispossession and socio-environmental conflicts caused by the expansion of agribusiness in Argentina. Journal of Agrarial Changes 15: 116-147. doi: 10.1111/joac.12057.

Ceballos G, Ehrlich PR, Dirzo R (2017) Biological annihilation via the ongoing sixth mass extinction signaled by vertebrate population losses and declines. Proceedings of the National Academy of Sciences 114(30): 6089-6096.

Cordeu E, Siffredi A (1971) De la algarroba al algodón: movimientos milenaristas del Chaco argentino. Juárez Editor, Buenos Aires, Argentina.
Cordeu E, De los Ríos M (1982) Un enfoque estructural de las variaciones socioculturales de los Cazadores Recolectores del Gran Chaco. Revista del Centro de Estudios Antropológicos 17: 1.

Dahal S, Nepal SK, Maschuett MA (2014) Examining Marginalized Communities and Local Conservation Institutions: The Case of Nepal's Annapurna Conservation Area. Environmental Management 53: 219-230.

Dasso MC (2010) Memorias y representaciones sobre el criollo del chaco argentino. Confluenze. Rivista di Studi Iberoamericani 2(2): 236-253.

Descola P (2012) Más allá de naturaleza y cultura. Amorrortu, Buenos Aires, Argentina.

FAO (1998). Wildlife utilization and food security in Africa. FAO Conservation Guide, Rome, Italy. 110 pp.

Dinerstein E, Olson DM, Graham DJ,Webster AL, Primm SA, Bookbinder MP, Ledec G (1995) A Conservation Assessment of the Terrestrial Ecoregions of Latin America and the Caribbean. The World Wildlife Fund and The World Bank, Washington/District of Columbia, USA.

Fraser DJ, Coon T, Prince MR, Dion $R$, Bernatchez $L$ (2006) Integrating traditional and evolutionary knowledge in biodiversity conservation: a population level case study. Ecology and Society 11(2): 4.

Gadgil M, Berkes F, Folke C (1993) Indigenous knowledge for biodiversity conservation. Ambio 22(2-3): 151-156.

Galinier J, Lagarriga I, Perrin M (1995) Lógica Chamánica. Chamanismo en Latinoamérica: Una revisión conceptual. México, Plaza y Valdés: 1-20.

Gallardo G, Nuñez A, Pacheco LF, Ruiz-García M (2009) Conservación del puma en el Parque Nacional Sajama (Bolivia): Estado poblacional y alternativas de manejo. Mastozoología Neotropical 16(1): 59-68.

Hansen MC, Ptapov PV, Moore R, Hancher M, Turubanova SA, Tyukavina A, Thau SV, Goetz SJ, et al. (2013) High-resolution global maps of 21st-century forest cover change. Science 342: 850-853. 
Gordillo G (1993) La actual dinámica económica de los cazadores recolectores de Gran Chaco y los deseos imaginarios del esencialismo. Publicar - Antropología y Ciencias Sociales (3): 73-96.

Ingold T. 1986. The appropriation of nature. Essays on human ecology and social relations. Manchester University Press. Manchester, UK.

Manfredo J, Dayer AA (2004) Concepts for exploring the social aspects of human-wildlife conflict in a global context. Human Dimensions of Wildlife 9: 317-328.

Medrano C (2014) Zoo-sociocosmología qom: seres humanos, animales y sus relaciones en el Gran Chaco. Journal de la Société des Américanistes 100(1): 233-265.

Metraux A (1946) Ethnography of the Chaco. In: Steward JH (ed) Handbook of South American Indians. Washington, USA. 197-370 pp.

Morello J, Rodriguez A (2009) El Chaco sin bosques: la Pampa o el desierto del futuro. GEPAMA y UNESCO- Programa sobre el Hombre y la Biósfera, Buenos Aires, Argentina. 492pp

Morello J, Matteucci SD, Rodríguez AF, Silva M (2012) Ecorregions and ecosystem complexes of Argentina (Spanish). Orientación Gráfica Editora, Buenos Aires, Argentina.

Nasi R, Taber A, Van Vliet N (2011) Empty forests, empty stomachs? Bushmeat and livelihoods in the Congo and Amazon Basins. International Forestry Review 13(3): 355-368.

Ojasti J, Dallmeier F (2000) Wildlife management in the Neotropics (Spanish). Smithsonian Institution/Monitoring and Assessment of Biodiversity (MAB), Washington DC, EUA

Palmer J (2005) The wichi's good will, an indigenous spirituality (Spanish). APCD/ CECAZO/EPRAZOL, Grupo de Trabajo Ruta 81, Formosa, Salta.

Peres CA (1996) Population status of whitelipped and collared peccaries in hunters and non-hunted Amazonian forests. Biological Conservation 77: 115-123.

Periago ME, Chillo V, Ojeda RA (2014) Loss of mammalian species from the South American Gran Chaco: empty savanna syndrome? Mammalogical Review 45. doi: 10.1111/mam.12031.
Persha L, Agrawal A, Chhatre A (2011) Social and ecological synergy: local rulemaking, forest livelihoods, and biodiversity conservation. Science 331: 1606-1608.

Peterson MN, Hansen HP, Peterson MJ, Peterson TR (2011) How hunting strengthens social awareness of coupled human-natural systems. Wildlife Biology in Practice 6(2): 127143.

Prober SM, O'Connor MH, Walsh FJ (2011) Australian Aboriginal peoples' seasonal knowledge: a potential basis for shared understanding in environmental management. Ecology and Society 16(2): 12.

Quiroga VA, Noss AJ, Paviolo A, Boaglio GI, Di Bitetti MS (2016) Puma density, habitat use and conflict with humans in the Argentine Chaco. Journal for Nature Conservation 31: 915.

Redford KH, Robinson JG (1987). The game of choice: patterns of Indian and colonist hunting in the Neotropics. American Anthropologist 89(3): 650-667.

Rodriguez Mir J (2016) La lucha por el capital y la lucha por la subsistencia. La violencia del sistema capitalista en los indígenas wichí del Chaco argentino. Antropología Experimental 16 (24): 365-379.

Robinson JG, Bennett EL (2000) Hunting for Sustainability in Tropical Forests. Columbia University Press, New York NY, USA.

Scarpa GF (2009) Etnobotánica médica de los indígenas chorote y su comparación con la de los criollos del Chaco semiárido (Argentina). Darwiniana 47(1): 92-101.

Scarpa GF (2004) Medicinal plants used by the Criollos of Northwestern Argentine Chaco. Journal of Ethnopharmacology 91(1): 115-135.

Scruton R (2010) The sacred pursuit reflections on the literature of hunting. In: Kowalsky $\mathrm{N}$ (Ed). Hunting-Philosophy for Everyone: In Search of the Wild Life. Blackwell, London, UK. pp 187-197.

Silvius KM, Bodmer RE, Fragoso JMV (2004) People in Nature: Wildlife Conservation in South and Central America. Columbia University Press, New York NY, USA.

St John FA, Edwards-Jones G, Jones JP (2011) Conservation and human behaviour: lessons from social psychology. Wildlife Research 37(8): 658-667. 
Suárez ME (2012) Spirits related with the forest and its plants in the world of the Wichi people of the Semiarid Chaco, Salta, Argentina (Spanish). In: Arenas P (Ed) Ethnobotany in arid and semiarid areas of the Southern Cone of South America. CEFYBO, CONICET, UBA, Buenos Aires, Argentina. pp 145-178.

Sušnik B (1985) Los aborígenes del Paraguay: Aproximación a las creencias de los indígenas. Museo Etnográfico Andrés Barbero, Asunción, Paraguay.

Teel TL, Manfredo JM, Stinchfield MH (2007) The Need and Theoretical Basis for Exploring Wildlife Value Orientations Cross-Culturally. Human Dimensions of Wildlife: An International Journal 12: 297-305. doi: 10.1080/10871200701555857
Toledo BA, Trillo C (2018) Practices and spaces by gender: landscapes and rural tasks of livestock producers of the Sierras Chicas from Córdoba, Argentina. Ethnobiology and Conservation $7: 8$

Treves A, Wallace RB, White S (2009) Participatory planning of interventions to mitigate human-wildlife conflicts. Conservation Biology 23: 1577-1587.

UN; United Nations, Secretariat of the Permanent Forum on Indigenous Issues (2009) State of the world's Indigenous peoples. United Nations Print, New York NY, USA.

Viveiros de Castro E (2013) La mirada del Jaguar. Tinta Limón, Buenos Aires, Argentina.

Viveiros de Castro E (1998) Cosmological deixis and Amerindian perspectivism. Journal of the Royal Anthropological Institute 4(3): 469488.
Received: 03 July 2018

Accepted: 06 August 2018

Published: 24 August 2018 